BNL-113651-2017-JA

\title{
Importance of Low Dimensional CeOx Nanostructures in Pt/CeOx-TiO2 Catalysts for the Water-Gas Shift Reaction
}

\author{
Si Luo, Laura Barrio, Thuy-Duong Nguyen-Phan, Dimitriy Vovchok, \\ Aaron C. Johnston-Peck, Wenqian Xu, Eric A. Stach, \\ and José A. Rodriguez, and Sanjaya D. Senanayake
}

Submitted to JPCC

March 2017

Chemistry Department

Brookhaven National Laboratory

\author{
U.S. Department of Energy \\ USDOE Office of Science (SC), \\ Basic Energy Sciences (BES) (SC-22)
}

Notice: This manuscript has been authored by employees of Brookhaven Science Associates, LLC under Contract No. DE- SC0012704 with the U.S. Department of Energy. The publisher by accepting the manuscript for publication acknowledges that the United States Government retains a non-exclusive, paid-up, irrevocable, world-wide license to publish or reproduce the published form of this manuscript, or allow others to do so, for United States Government purposes. 


\section{DISCLAIMER}

This report was prepared as an account of work sponsored by an agency of the United States Government. Neither the United States Government nor any agency thereof, nor any of their employees, nor any of their contractors, subcontractors, or their employees, makes any warranty, express or implied, or assumes any legal liability or responsibility for the accuracy, completeness, or any third party's use or the results of such use of any information, apparatus, product, or process disclosed, or represents that its use would not infringe privately owned rights. Reference herein to any specific commercial product, process, or service by trade name, trademark, manufacturer, or otherwise, does not necessarily constitute or imply its endorsement, recommendation, or favoring by the United States Government or any agency thereof or its contractors or subcontractors. The views and opinions of authors expressed herein do not necessarily state or reflect those of the United States Government or any agency thereof. 
Importance of Low Dimensional $\mathrm{CeO}_{x}$ Nanostructures in $\mathrm{Pt} / \mathrm{CeO}_{\mathrm{x}}-\mathrm{TiO}_{2}$ Catalysts for the WaterGas Shift Reaction

Si Luo, ${ }^{\mathrm{a}, \mathrm{d}}$ Laura Barrio, ${ }^{\mathrm{b}}$ Thuy-Duong Nguyen-Phan, ${ }^{\mathrm{a}}$ Dimitriy Vovchok, ${ }^{\mathrm{a}, \mathrm{d}}$ Aaron C. Johnston-Peck, ${ }^{\mathrm{c}}$ Wenqian Xu, ${ }^{\mathrm{a}}$ Eric A. Stach, ${ }^{\mathrm{c}}$ and José A. Rodriguez, ${ }^{\mathrm{a}, \mathrm{d}}$ and Sanjaya D. Senanayake ${ }^{\mathrm{a} *}$

${ }^{a}$ Chemistry Department, Brookhaven National Laboratory, Upton, NY 11973, USA.

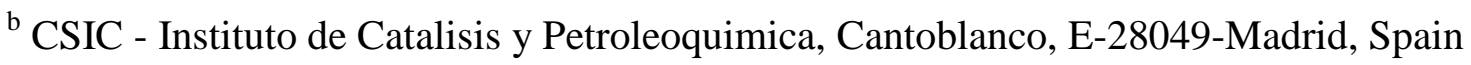

${ }^{\mathrm{c}}$ Center for Functional Nanomaterials, Brookhaven National Laboratory, Upton, NY 11973, USA.

${ }^{\mathrm{d}}$ Department of Chemistry, Stony Brook University, Stony Brook, NY 11794, USA Email: *ssenanay@bnl.gov 


\begin{abstract}
$\mathrm{CO}_{2}$ and $\mathrm{H}_{2}$ production from the water-gas shift (WGS) reaction was studied over $\mathrm{Pt} / \mathrm{CeO}-\mathrm{TiO}_{2}$ catalysts with incremental loadings of $\mathrm{CeO}_{\mathrm{x}}$, that adopts variations in the local morphology. The lowest loading of $\mathrm{CeO}_{\mathrm{x}}(1 \mathrm{wt} \% \sim 0.5$ at\%) that is configured in its smallest dimensions exhibited the best WGS activity over larger dimensional structures. We attribute this to several factors including the ultrafine dispersed one-dimensional nanocluster geometry, a large concentration of $\mathrm{Ce}^{3+}$ and enhanced reducibility of the low loadings. We utilized several in situ experiments to monitor the active state of the catalyst during the WGS reaction. X-ray diffraction (XRD) results showed lattice expansion that indicated reduced ceria was prevalent during the WGS reaction. On the surface, $\mathrm{Ce}^{3+}$ related hydroxyl groups were identified by diffuse reflectance infrared Fourier-transform spectroscopy (DRIFTS). The enhanced reducibility of the catalyst with the introduction of ceria was further revealed by $\mathrm{H}_{2^{-}}$ temperature programed reduction $\left(\mathrm{H}_{2}-\mathrm{TPR}\right)$ and good thermal stability was confirmed by in situ environmental transmission electron microscopy (ETEM). We also investigated the formation of the low dimensional structures during catalyst preparation, through a two-stage crystal growth of ceria crystallite on $\mathrm{TiO}_{2}$ nanoparticle: fine crystallites $\sim 1 \mathrm{D}$ formed at $\sim 250{ }^{\circ} \mathrm{C}$, followed by crystal growth into 2D chain and 3D particle from $250 \sim 400{ }^{\circ} \mathrm{C}$.
\end{abstract}




\section{INTRODUCTION}

The water-gas shift reaction $\left(\mathrm{CO}+\mathrm{H}_{2} \mathrm{O} \rightarrow \mathrm{H}_{2}+\mathrm{CO}_{2}\right)$ is one of the most important industrial catalytic processes for clean $\mathrm{H}_{2}$ production and purification. ${ }^{1-7}$ The common industrial catalysts used for the WGS reaction are pyrophoric, i.e. mixtures of $\mathrm{Fe}-\mathrm{Cr}$ or $\mathrm{Zn}-\mathrm{Al}-\mathrm{Cu}$ oxides, and require lengthy and complex activation steps before usage. ${ }^{4}$ Several classes of novel, active catalysts have been recently developed to improve performance and stability: Model and powder catalysts in which noble metals $(\mathrm{Au}, \mathrm{Pt}, \mathrm{Ru})$ are supported on plain metal oxides $\left(\mathrm{CeO}_{2}, \mathrm{TiO}_{2}, \mathrm{ZrO}_{2}, \mathrm{CuO}, \mathrm{ZnO}, \mathrm{SiO}_{2}\right)$, transition metal (Ni, W, Ce, $\mathrm{Cu}$ ) doped oxides, and mixed metal oxides $\left(\mathrm{CeO}_{2}-\mathrm{TiO}_{2}, \mathrm{CuO}-\mathrm{CeO}_{2}, \mathrm{CeO}_{2}-\mathrm{ZrO}_{2}\right)$. ${ }^{1-16}$

Among them, ceria based materials are one of the most promising WGS components owing to the inherent $\mathrm{Ce}^{4+} / \mathrm{Ce}^{3+}$ redox cycle, oxygen storage capability and excellent thermal / chemical stability. ${ }^{1,5,6,8,9,11-14} \mathrm{CeO}_{2}$ nanoparticles with a mean size less than $10 \mathrm{~nm}$ exhibit quantum confinement effect and significant cell parameter enlargement due to large quantity of $\mathrm{Ce}^{3+}$ centers and consequent formation of oxygen vacancy defects. ${ }^{17,18}$ It is noteworthy that the addition of Pt nanoparticles on $\mathrm{CeO}_{2}$ significantly improve the WGS activity via a redox mechanism in which reduced platinum interacts with $\mathrm{CO}$ whereas partially reduced $\mathrm{CeO}_{\mathrm{x}}$ species dissociate water. ${ }^{13}$ It has been proven that the catalytic behavior of $\mathrm{CeO}_{2}$ for the WGS reaction could be enhanced by the presence of second oxide as a substrate, i.e. $\mathrm{TiO}_{2}$, so that the size, dispersion and surface properties of $\mathrm{CeO}_{2}$ can be successfully controlled. ${ }^{6,13}$ Jose. J. Plata ${ }^{14}$ et al. reported the synergistic effects at the metal oxide interface in $\mathrm{Cu} / \mathrm{CeO}_{\mathrm{x}}-\mathrm{TiO}_{2}(110)$ system and illustrates the importance of the phase of $\mathrm{CeO}_{\mathrm{x}}$ to promote the WGS catalytic performance. $\mathrm{Pt} / \mathrm{CeO}_{\mathrm{x}}-\mathrm{TiO}_{2}$ was found to have improved WGS activity at a loading of 6 wt\% of $\mathrm{CeO}_{\mathrm{x}}$ on $\mathrm{TiO}_{2}$ because it facilitated the dispersion of small particles of $\mathrm{Pt}$ and improved the reducibility of the ceria component at low temperatures. ${ }^{13}$ Recently, we have identified the crucial role of hierarchical heterogeneity at the $\mathrm{CeO}_{x}-\mathrm{TiO}_{2}$ interface in $\mathrm{H}_{2}$ and $\mathrm{O}_{2}$ evolution from water photocatalytic splitting. $\mathrm{CeO}_{\mathrm{x}}$ distributed on the anatase $\mathrm{TiO}_{2}$ support in different geometries according 
to its loading content: Ultrafine dispersed one-dimensional (1D) clusters smaller than $1 \mathrm{~nm}(1 \mathrm{wt} \%)$, additional two-dimensional (2D) trapezoidal chains and short islands (3 wt\%), and additional large three-dimensional (3D) hemispherical nanoparticles (6 wt\%). We have demonstrated that a low dimensional geometry of $\mathrm{CeO}_{\mathrm{x}}$ with enriched $\mathrm{Ce}^{3+}$ concentration at the $\mathrm{CeO}_{\mathrm{x}}$ surface and at the $\mathrm{CeO}_{\mathrm{x}^{-}}$ $\mathrm{TiO}_{2}$ interface provided unique electronic and geometrical properties that are beneficial to the photocatalytic activity. ${ }^{19}$

Therefore, inspired from our previous work, we report herein the use of $\mathrm{Pt} / \mathrm{CeO}_{\mathrm{x}}-\mathrm{TiO}_{2}$ as a catalyst for the WGS reaction with the aim of further elucidate the importance of the $\mathrm{CeO}_{\mathrm{x}}$ structure. We investigate the crucial role of $\mathrm{CeO}_{\mathrm{x}}$ dimensions and geometry in correlation to the WGS activity by in situ XRD and DRIFTS under reaction conditions. The catalyst reducibility is probed by $\mathrm{H}_{2}$-TPR and thermal stability of morphological structure is proved by in situ environmental TEM. The crystal growth of $\mathrm{CeO}_{\mathrm{x}}$ on $\mathrm{TiO}_{2}$ support is further investigated by means of TGA/DTA, time-resolved in situ XRD, PDF and scanning TEM (STEM).

\section{EXPERIMENTAL}

\section{Catalyst preparation}

$\mathrm{CeO}_{\mathrm{x}}-\mathrm{TiO}_{2}$ samples using commercial anatase $\mathrm{TiO}_{2}$ nanoparticles were synthesized by wet impregnation method using cerium nitrate precursor, and labeled as $\mathrm{xCeTi}$ with $\mathrm{x}=1,3$, and 6 wt\% $\mathrm{CeO}_{\mathrm{x}}$ (nominal contents, as-impregnated samples). Subsequently, $\mathrm{CeO}_{\mathrm{x}}-\mathrm{TiO}_{2}$ catalysts were calcined to $500{ }^{\circ} \mathrm{C}$, prior to being loaded with $0.5 \mathrm{wt} \% \mathrm{Pt}$ from $\mathrm{H}_{2} \mathrm{PtCl}_{6}$ solution by wet impregnation route and denoted as PtxCeTi (where $\mathrm{x}=1,3$, and $6 \mathrm{wt} \% \mathrm{CeO}_{2}$ ). The experimental details were described in previous report. ${ }^{19}$

\section{Ex situ characterization}


Annular dark-field scanning transmission electron microscopy (STEM) images and energy electron loss spectra (EELS) were collected with an aberration-corrected Hitachi HD-2700C operating at an accelerating voltage of $200 \mathrm{kV}$ and using a probe convergence semi-angle of $23 \mathrm{mrad}$. The inner collection angle of the annular dark field detector was approximately 53 mrad while the collection angle for energy electron loss spectroscopy was $20 \mathrm{mrad}$.

\section{In situ characterization during thermal treatment}

Thermogravimetric analysis (TGA) and differential thermal analysis (DTA) were performed on a Mettler Toledo TGA/SDTA 851 apparatus. Typically, 30-40 mg of the powder catalyst were heated from 298 to $1373 \mathrm{~K}$ at a rate of $10 \mathrm{~K} \mathrm{~min}^{-1}$ under air and $10 \% \mathrm{H}_{2} / \mathrm{N}_{2}$ atmospheres.

In situ time-resolved X-ray diffraction (TR-XRD) patterns and atomic pair distribution function (PDF) profiles were collected at beamline X7B $(\lambda=0.3196 \AA)$ of the National Synchrotron Light Source (NSLS) at BNL. $5 \mathrm{mg}$ of powder were loaded into a quartz capillary mounted on a Clausen flow cell. As-prepared $\mathrm{CeO}_{\mathrm{x}}-\mathrm{TiO}_{2}$ samples were heated at $10{ }^{\circ} \mathrm{C} \mathrm{min}^{-1}$ from 25 to $600{ }^{\circ} \mathrm{C}$ under $\mathrm{O}_{2}$ atmosphere. Experiment details were described elsewhere. ${ }^{12}$ The Rietveld refinement was conducted by using the General Structure Analysis System II (GSAS II) software. ${ }^{20}$

In situ environmental transmission electron microscopy (ETEM) images were recorded on an aberration-corrected FEI Titan 80-300 operating at $300 \mathrm{kV}$. STEM and ETEM characterizations were conducted at the CFN-BNL. The $6 \mathrm{wt} \% \mathrm{CeO}_{\mathrm{x}}-\mathrm{TiO}_{2}$ sample was imaged under $\sim 1.1 * 10^{-3}$ torr $\mathrm{H}_{2}$ at elevated temperatures: $100{ }^{\circ} \mathrm{C}, 200^{\circ} \mathrm{C}$ and $300^{\circ} \mathrm{C}$, using a furnace-type heating holder (Gatan, Inc.).

$\mathrm{H}_{2}$-temperature programed reduction $\left(\mathrm{H}_{2}-\mathrm{TPR}\right)$ of the calcined samples was carried out using a Micromeritics 2900 instrument in a U-shaped quartz reactor. Prior to the reduction test, $30 \mathrm{mg}$ of powder were flushed with Helium at $150{ }^{\circ} \mathrm{C}$ for $15 \mathrm{~min}$ and then cooled down to room temperature. 
TPR profiles were obtained by heating the sample under a $10 \% \mathrm{H}_{2} / \mathrm{Ar}$ flow $\left(50 \mathrm{~mL} \mathrm{~min}^{-1}\right.$ ) from $25{ }^{\circ} \mathrm{C}$ to $900{ }^{\circ} \mathrm{C}$ at a linearly programmed rate of $10^{\circ} \mathrm{C} \mathrm{min}^{-1}$.

\section{In situ Diffuse Reflectance Infrared Fourier Transform Spectroscopy (DRIFTS) and WGS activity}

In situ DRIFTS data of PtCeTi samples under WGS reaction condition were collected on a Bruker Equinox 55 FTIR spectrometer equipped with a modified Harrick Praying Mantis DRIFT cell. 5\% $\mathrm{CO} / \mathrm{He}$ was monitored by a calibrated flow meter with the flow rate of $20 \mathrm{~mL} \mathrm{~min}^{-1}$ and mixed with $\sim 3 \%$ water vapour by passing through a water bubbler. The system was stabilized at each elevated temperature step for $30 \mathrm{~min}$ and then 516 scans were collected to improve the signal to noise ratio. Instrument details could be found in previous report. $^{20}$

\section{In situ X-ray Diffraction and WGS activity}

In situ XRD experiments were carried out at beamline 17BM-B of the Advanced Photon Source at Argonne National Laboratory under WGS reaction condition. 10mg of powder sample was loaded into a 1.1mm OD, $0.9 \mathrm{~mm}$ ID quartz capillary mounted onto a Clausen microflow reactor cell. The WGS reactant gas mixture (5\% $\mathrm{CO}, 3 \% \mathrm{H}_{2} \mathrm{O}$ from bubbler, balance Helium) was introduced to the reactor at a flow rate of 20 scc per min. The sample was heated and cooled stepwise under reactant gas flow at a rate of $5^{\circ} \mathrm{C} / \mathrm{min}$ up to $400^{\circ} \mathrm{C}$ and subsequently cool down to room temperature. Diffraction data was collected continuously throughout the process, and product gas outflow was analyzed using an RGA 300 quadrupole mass spectrometer system. The phase composition and lattice parameters were also analyzed by Rietveld refinement using the General Structure Analysis System II (GSAS II) software. ${ }^{20}$

\section{RESULTS AND DISCUSSION}

\section{Structure evolution of $\mathrm{CeO}_{x}-\mathrm{TiO}_{2}$ during oxidative annealing}


The thermal behavior of the mixed metal oxide systems was studied by TGA/DTA analysis. Fig. 1 shows the compositional change of as-impregnated CeTi samples as of function of $\mathrm{CeO}_{\mathrm{x}}$ loading in air. Four distinct stages can be seen in TGA/DTA curves as annealing in air although different $\mathrm{CeO}_{\mathrm{x}}$ loadings reveal different behaviors. The total weight loss occurs remarkably in as-impregnated 3CeTi and $6 \mathrm{CeTi}$, about $4.5 \%$ and $9.5 \%$, respectively. The first weight loss below $170{ }^{\circ} \mathrm{C}$ is attributed to the removal of moisture residue and trapped $\mathrm{CO}_{2}$. The major weight loss associated with a large endothermal DTA peak takes place between 175 and $250{ }^{\circ} \mathrm{C}$, possibly stemming from the removal of structural hydroxyl groups and the release of $\mathrm{NO}_{\mathrm{x}}$ from the decomposition of nitrates from cerium precursors. This peak becomes sharp and intense in 6CeTi due to higher concentration of cerium precursors. Much smaller endothermic peak locates between 250 and $400{ }^{\circ} \mathrm{C}$ with less mass loss might be ascribed to the crystallization of amorphous and/or cerium hydroxide and the oxidation of $\mathrm{Ce}^{3+}$ to $\mathrm{Ce}^{4+}$. No significant weight loss was found beyond $400{ }^{\circ} \mathrm{C}$ until $720{ }^{\circ} \mathrm{C}$ where the anatase-to-rutile phase transformation of $\mathrm{TiO}_{2}$ occurs. It indicates that the presence of $\mathrm{CeO}_{\mathrm{x}}$ remarkably inhibits the phase transformation of the support that starts at $600{ }^{\circ} \mathrm{C}$. 

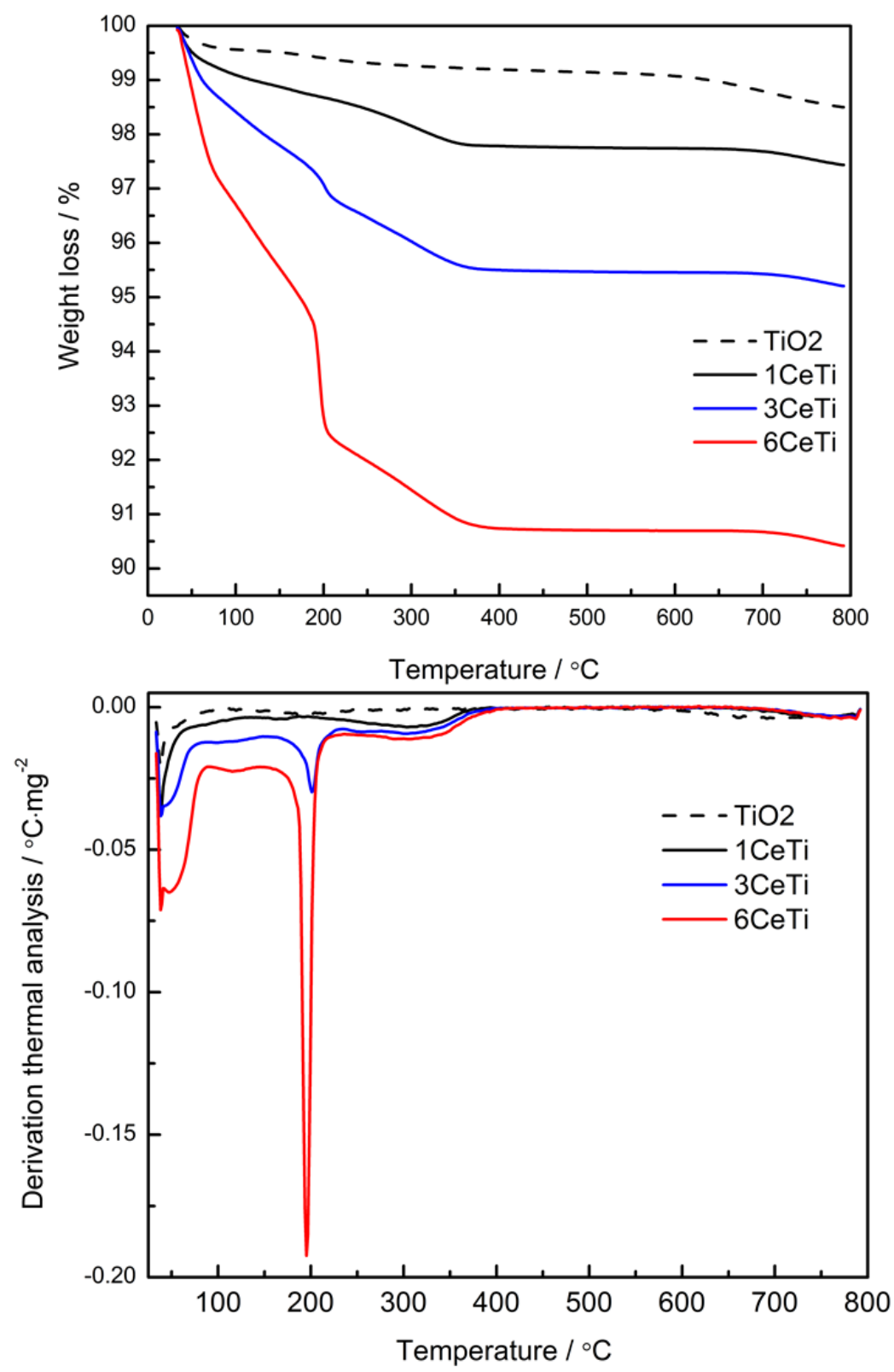

Figure 1. TGA (top) and DTA (bottom) analysis of as-impregnated xCeTi samples in air.

The morphology evolution of a representative $\mathrm{CeO}_{\mathrm{x}}-\mathrm{TiO}_{2}$ sample was also studied by means of electron microscopy. Fig. 2 shows the STEM image of as-impregnated 6CeTi and its corresponding elemental mapping, confirming that the cerium species were well dispersed on the $\mathrm{TiO}_{2}$ support. After annealing in $\mathrm{O}_{2}$ to $600{ }^{\circ} \mathrm{C}$, crystalline ceria was generated on the surface of $\mathrm{TiO}_{2}$ while liberating $\mathrm{H}_{2} \mathrm{O}$. (STEM images after annealing were present in our previous work in reference ${ }^{19}$ ) 
(A)

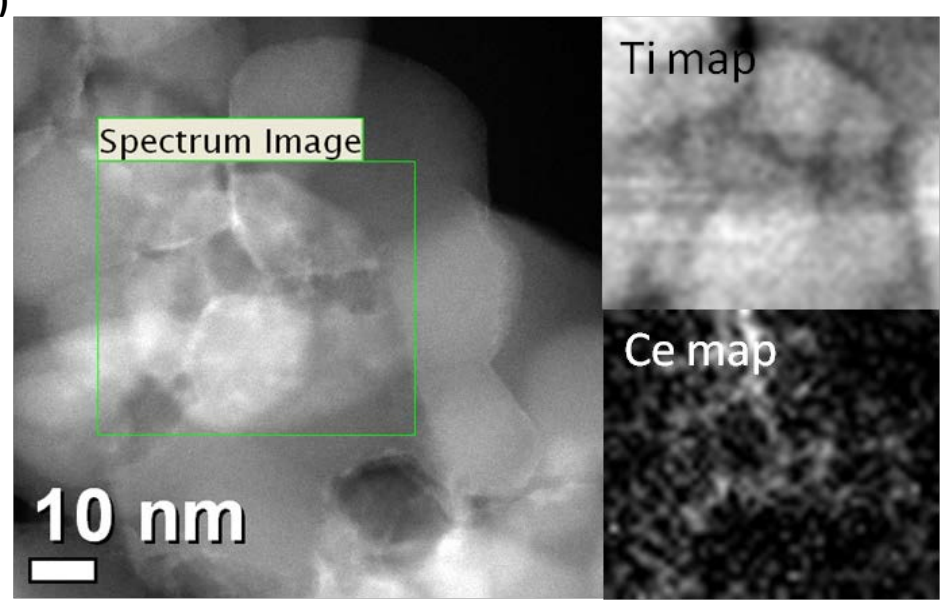

(B)

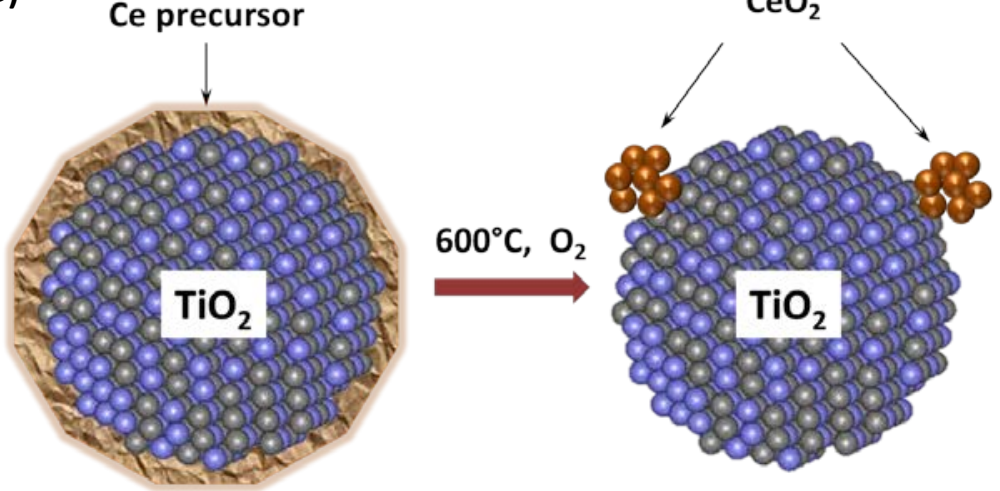

Figure 2. (A) STEM elemental map of as-impregnated $6 \mathrm{wt} \% \mathrm{CeO}_{\mathrm{x}}-\mathrm{TiO}_{2}$ and (B) schematic illustration describes the crystal growth of $\mathrm{CeO}_{2}$ onto $\mathrm{TiO}_{2}$ upon calcination.

In order to understand the growth mechanism of crystalline $\mathrm{CeO}_{2}$ on $\mathrm{TiO}_{2}$ surface, in situ XRD and PDF analysis were employed to provide more detailed studies. Fig. 3(A) displays the time-resolved XRD spectra for as-impregnated 6CeTi sample at different annealing temperatures. The crystallization of the ceria structure follows the process:

$$
4 \mathrm{Ce}(\mathrm{OH})_{3}(\mathrm{~s})+\mathrm{O}_{2}(\mathrm{~g}) \rightarrow 4 \mathrm{CeO}_{2}(\mathrm{~s})+6 \mathrm{H}_{2} \mathrm{O}(\mathrm{g})
$$

It can be seen that there was no crystalline $\mathrm{CeO}_{2}$ features until annealing at $200{ }^{\circ} \mathrm{C}$. A small and broadened peak in the range of $\sim 5.5$ to $6^{\circ}$, representative of amorphous phase, emerges at $\sim 250{ }^{\circ} \mathrm{C}$ 
which is consistent with the TGA/DTA result described above. This peak gradually grows and slightly shifts towards lower angle at $\sim 400{ }^{\circ} \mathrm{C}$. Such a growth obviously reveals the decomposition and crystallization of cubic fluorite $\mathrm{CeO}_{2}$ (space group $F m 3 m$ ) from amorphous and/or $\mathrm{Ce}(\mathrm{OH})_{3}$ upon heat treatment. The reflection at $5.8^{\circ}$ corresponding to $\mathrm{CeO}_{2}[111]$ becomes sharper concomitantly with the adjunct appearance of [200] peak at $6.8^{\circ}$, as elevating the temperature beyond $400{ }^{\circ} \mathrm{C}$. The evolution of $\mathrm{CeO}_{2}$ particle size and $\mathrm{Ce} / \mathrm{Ti}$ ratio obtained from sequential Rietveld refinement are presented in Fig. 3(B). When temperature increases from 200 to $\sim 450{ }^{\circ} \mathrm{C}$, the particle size of ceria crystallites shows a tremendous increase from $3 \mathrm{~nm}$ to $6 \mathrm{~nm}$. The $\mathrm{CeO}_{2}$ fluorite-type structure is stabilized up to $600{ }^{\circ} \mathrm{C}$ with the average size of $\sim 6.7 \mathrm{~nm}$ and a Ce/Ti ratio of 0.025 . An example of the XRD pattern fitting and analysis was included in supporting information (Figure S1).
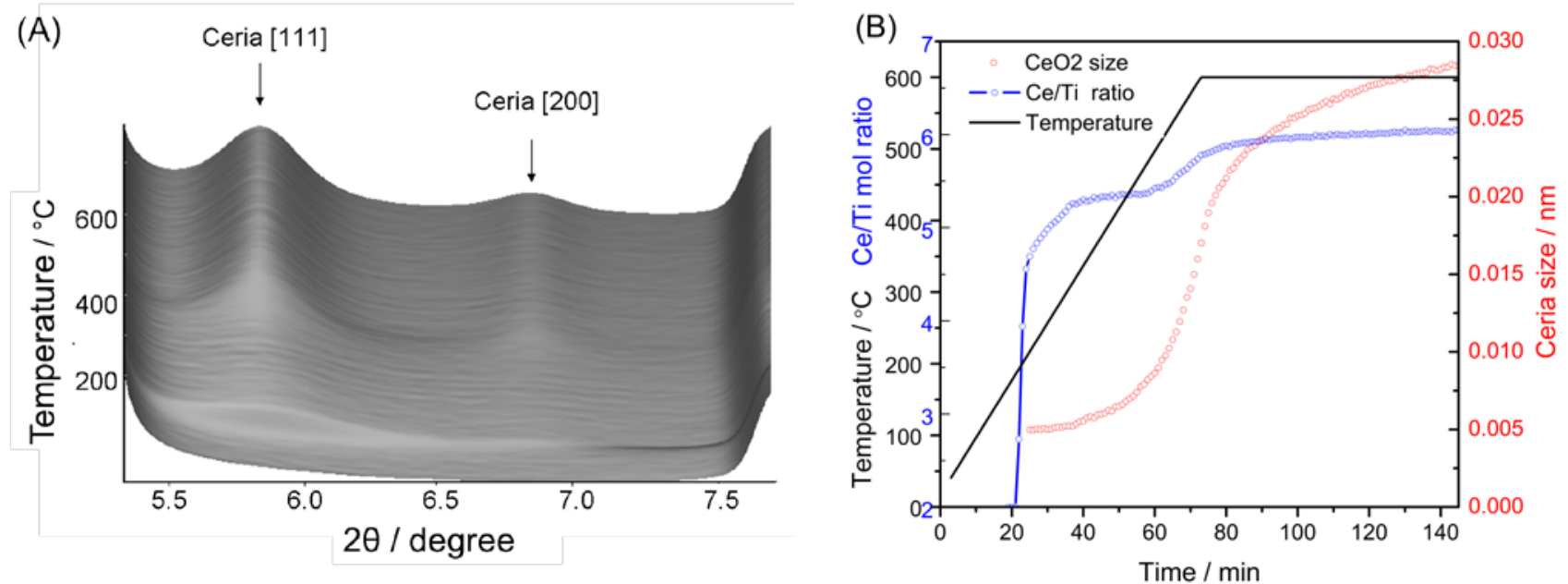

Figure 3. (A) Time-resolved XRD spectra of as-impregnated 6CeTi sample, (B) Rietveld refinement of ceria as a function of temperature: particle size and $\mathrm{Ce} / \mathrm{Ti}$ ratio.

The in situ XRD pattern shows the alteration in long-range crystal structure during the evolution of ceria crystallite. As a complementary investigation on the local atomic structure, we collected the total scattering to a large value of momentum transfer $Q(\sim 100)$. The real space atomic bond information 
was obtained by using Python/PDFgetX3 program. $G(r)$ function defines the probability of finding a pair of atoms at a certain interatomic distance $r$, while the integrated intensity is related to the coherence scattering lengths and the multiplicities of the atom. Fig. 4(A) shows the comparison of PDF profiles of a $\mathrm{CeO}_{2}$ nanoparticle standard, as-impregnated 6CeTi before calcination, during $600{ }^{\circ} \mathrm{C}$ in situ calcination and after calcination (cooling) in $\mathrm{O}_{2}$ at $600^{\circ} \mathrm{C}$. The intense peaks at $1.96 \AA$ and 3.05 $\AA$ are assigned to Ti-O and Ti-Ti pairs for the first neighbor coordination shell in $\left[\mathrm{TiO}_{6}\right]$ octahedral (the closet $\mathrm{O}$ shell around a Ti atom). The maximum at $3.83 \AA$ is ascribed to the second asymmetric TiTi/O-O coordination sphere. The line shape and peak position remain the same after annealing, indicating the stability of anatase $\mathrm{TiO}_{2}$ during the ceria crystallization process. However, the noticeable enhancement in intensity of the peak at $3.83 \AA$ after calcination can be due to the formation of Ce-Ce bonds during the crystallization of $\mathrm{CeO}_{2}$, which are located at the same position. The two small peaks at $2.27 \AA$ and $2.46 \AA$ are ascribed to the $\mathrm{Ce}-\mathrm{O}$ vector from $\mathrm{CeO}_{2}$ and the O-O bond distance from $\mathrm{TiO}_{2}$, respectively. The feature at $2.27 \AA$ slightly shifts and broadens, compared to pure $\mathrm{CeO}_{2}$, possibly due to the partial reduction of ceria at the $\mathrm{CeO}_{2}-\mathrm{TiO}_{2}$ interface and/or $\mathrm{CeO}_{2}$ surface. As seen in the color contour map presenting the in situ time-resolved PDF during the calcination process (Fig. 4(B)), the intensity diminution of all the peaks at high temperature can be attributed to thermal effects. Afterwards, the intensity significantly increases after the cooling process comparing to the intensity before calcination, indicating the growth of $\mathrm{CeO}_{2}$ fluorite-type structure in which the feature of Ce-O, Ce-Ce at $2.27 \AA$ and $3.83 \AA$, respectively, can be taken into account. 

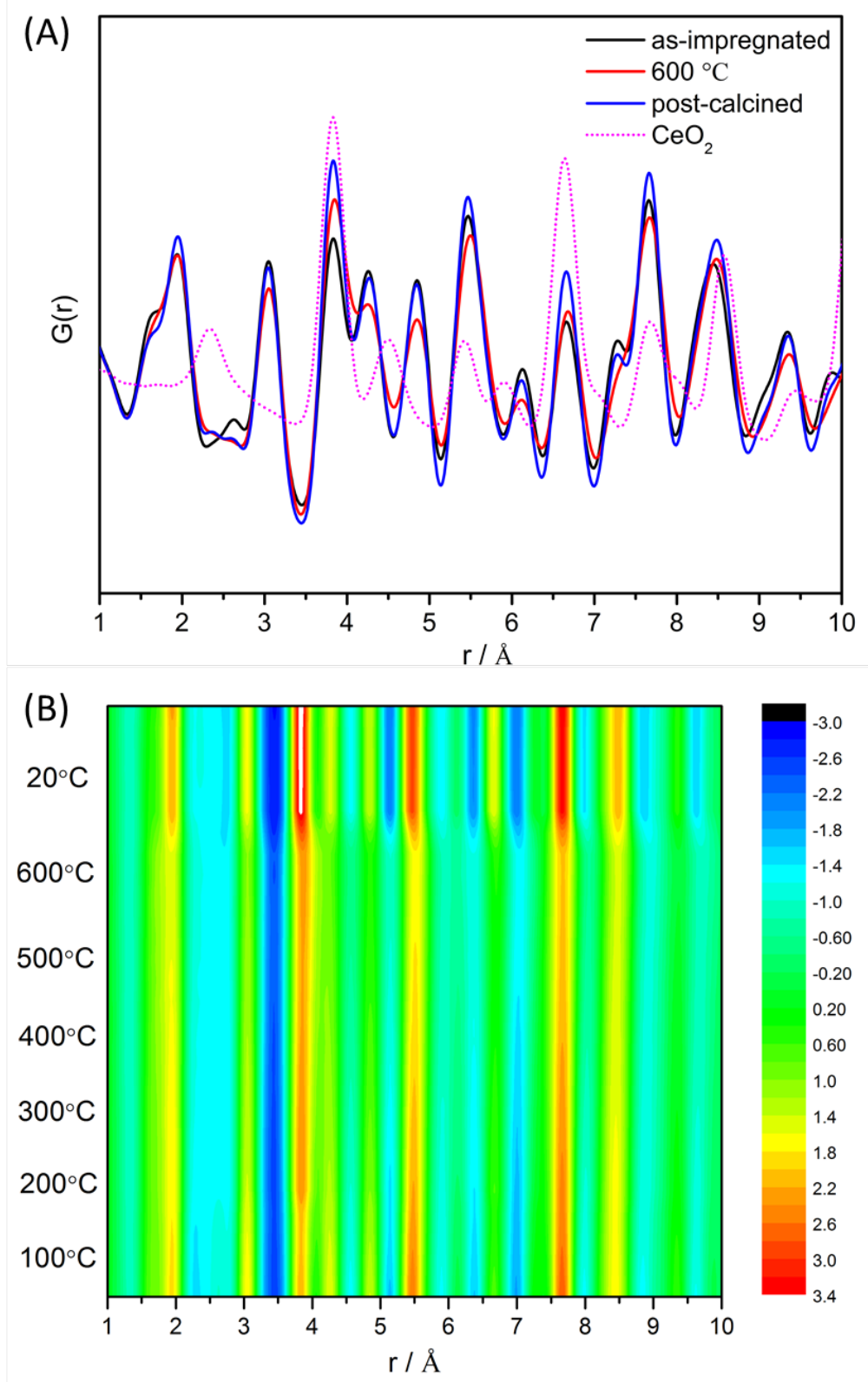

Figure 4. In situ PDF analysis of as-impregnated 6CeTi sample during heat treatment from room temperature to $600^{\circ} \mathrm{C}$ and then cooling down: (A) comparison of PDF profiles at different temperature: (B) color contour map of the full calcination process.

\section{$\mathrm{CeO}_{\mathrm{x}}-\mathrm{TiO}_{2}$ reducibility}

Fig. 5 displays the $\mathrm{H}_{2}$-TPR profiles where the hydrogen uptake as a function of temperature was plotted. $\mathrm{TiO}_{2}$ and $\mathrm{CeO}_{\mathrm{x}}-\mathrm{TiO}_{2}$ catalysts show two main asymmetric features in the range of 200-600 ${ }^{\circ} \mathrm{C}$. It is obvious that the amount of $\mathrm{H}_{2}$ consumption is proportional to $\mathrm{CeO}_{\mathrm{x}}$ concentration, implying the 
enhancement in surface reduction in the presence of $\mathrm{CeO}_{\mathrm{x}}{ }^{22}$ The larger the $\mathrm{H}_{2}$ consumption, the higher the surface oxygen concentration, indicating the significant reducibility of mixed oxide systems. In pure $\mathrm{TiO}_{2}$, the position of two poorly resolved reduction features with maxima at $\sim 270$ and $554{ }^{\circ} \mathrm{C}$ could be ascribed to the removal of loose capping oxygen and surface oxygen by $\mathrm{H}_{2}{ }^{13,23}$ It has been reported that the reduction of $\mathrm{CeO}_{2}$ involves two processes: the initial loss of surface oxygen at low temperature $\left(\sim 410{ }^{\circ} \mathrm{C}\right)$ and further removal of bulk oxygen at higher temperature $\left(\sim 510{ }^{\circ} \mathrm{C}\right) .{ }^{22}$ The reduction peak at low temperature obviously broadens and increases with increasing $\mathrm{CeO}_{\mathrm{x}}$ content, probably due to the energetic differences of $\mathrm{CeO}_{\mathrm{x}}$ dependent of the degree of interaction with the $\mathrm{TiO}_{2}$ support. ${ }^{22}$ Since surface oxygen removal by $\mathrm{H}_{2}$ began at $410{ }^{\circ} \mathrm{C}$ in pure $\mathrm{CeO}_{2}{ }^{22}$ small ceria structure supported on $\mathrm{TiO}_{2}$ nanoparticles exhibit significant lower reduction temperature. The feature at high temperature with a left shoulder at $\sim 500{ }^{\circ} \mathrm{C}$ becomes relatively intense and sharp, shifting downscale to 526,536 and $535{ }^{\circ} \mathrm{C}$ for $1 \mathrm{CeTi}$, 3CeTi and 6CeTi, respectively, suggesting the reducibility of bulk and surface species on $\mathrm{TiO}_{2}$, and the concomitant reduction of cerium ions that might be related with easily removable surface oxygen from $\mathrm{CeO}_{x}$ entities in close contact with $\mathrm{TiO}_{2}$ surface. ${ }^{13,23}$ Once $\mathrm{Ce}^{3+}$ species appear, the oxygen vacancy will be created to preserve the electrostatic balance. Since $\mathrm{CeO}_{\mathrm{x}}$ in 1 CeTi catalyst presents in a highly dispersed form with abundant $\mathrm{Ce}^{3+}$ and surface defects as shown in previous report, ${ }^{19}$ the reduction of either ceria or titania starts at lower temperature compared to others, therefore leading much better WGS performance compared to others. The reduction of both $\mathrm{TiO}_{2}$ and $\mathrm{CeO}_{\mathrm{x}}$ is consistent with the in situ XRD refinement aforementioned in which the ceria lattice parameter increases with raising temperature from $200{ }^{\circ} \mathrm{C}$ to $300{ }^{\circ} \mathrm{C}$ in reducing environment. The lattice expansion contributes to the structure distortion, leading to a high oxygen deficiency upon $\mathrm{H}_{2}$ reduction. The in situ DRIFTS results are consistent with the $\mathrm{H}_{2}$-TPR profiles in which the reduction of bulk $\mathrm{CeO}_{2}$ happens above $500{ }^{\circ} \mathrm{C}$. It is noteworthy that the reducibility, which correlates with the oxygen storage capacity as well as $\mathrm{Ce}^{4+} \leftrightarrows \mathrm{Ce}^{3+}$ and $\mathrm{Ti}^{4+} \leftrightarrows \mathrm{Ti}^{3+}$ redox cycles, is significantly enhanced by adding small amount of ceria onto the titania support. ${ }^{22}$ 


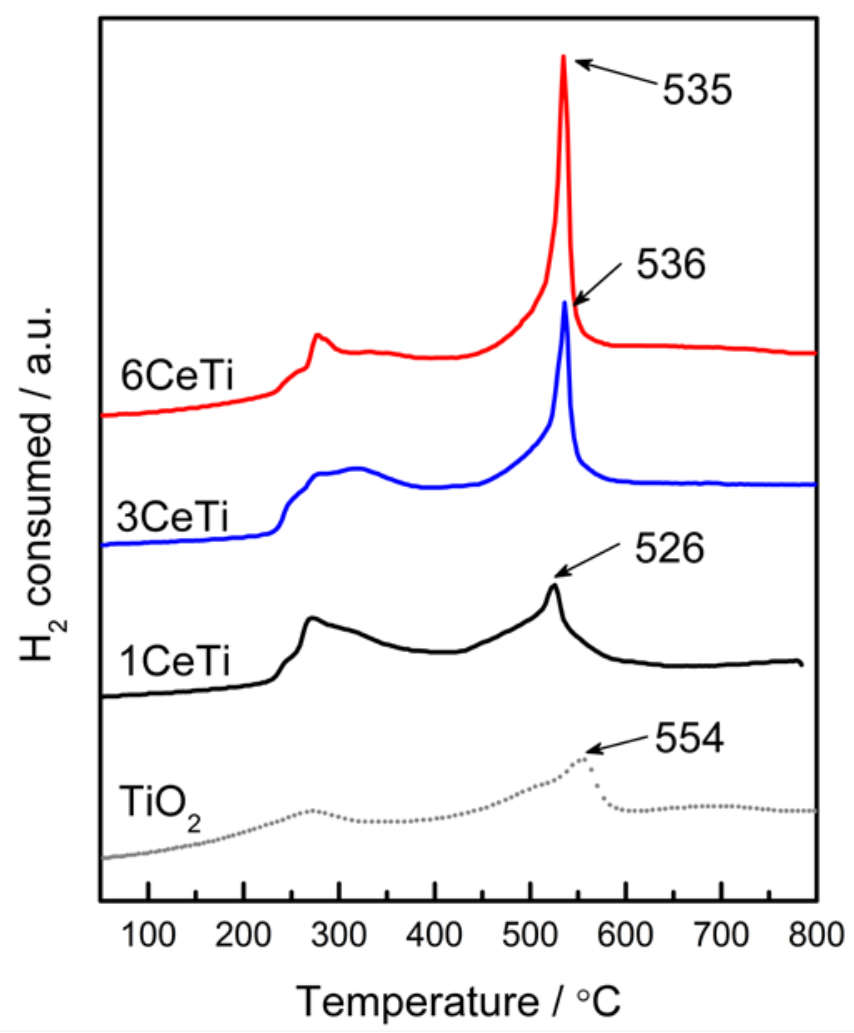

Figure 5. $\mathrm{H}_{2}$-TPR profiles of $\mathrm{TiO}_{2}$ standard and xCeTi samples.

On the other hand, we have directly observed the local morphological evolution of $\mathrm{CeO}_{\mathrm{x}}-\mathrm{TiO}_{2}$ system under reactive environment by in situ imaging. Fig. 6 shows the ETEM images of the 6CeTi sample annealed at 100,200 and $300{ }^{\circ} \mathrm{C}$ in $\sim 1.1 \times 10^{-1}$ torr $\mathrm{H}_{2}$. It can be seen that crystalline nanoparticles of $\mathrm{CeO}_{\mathrm{x}}$ deposit onto $\mathrm{TiO}_{2}$ support and the crystalline structure is retained with increasing temperature. $\mathrm{A}$ well-ordered structure of ceria in the atmosphere of $\mathrm{H}_{2}$ at different temperatures strongly confirms the good stability of the 6CeTi sample under reducing condition. The electron microscopy images and $\mathrm{H}_{2}$ TPR result are in agreement with our previous report that $6 \mathrm{CeTi}\left(\mathrm{Ce}^{3+} / \mathrm{Ce}^{4+}\right.$ atomic ratio of 0.28$)$, shows lower reducibility at low temperature. It indicates that the $\mathrm{CeO}_{2}$ and $\mathrm{TiO}_{2}$ crystal structures are quite stable up to $300{ }^{\circ} \mathrm{C}$ in $\mathrm{H}_{2}$. 


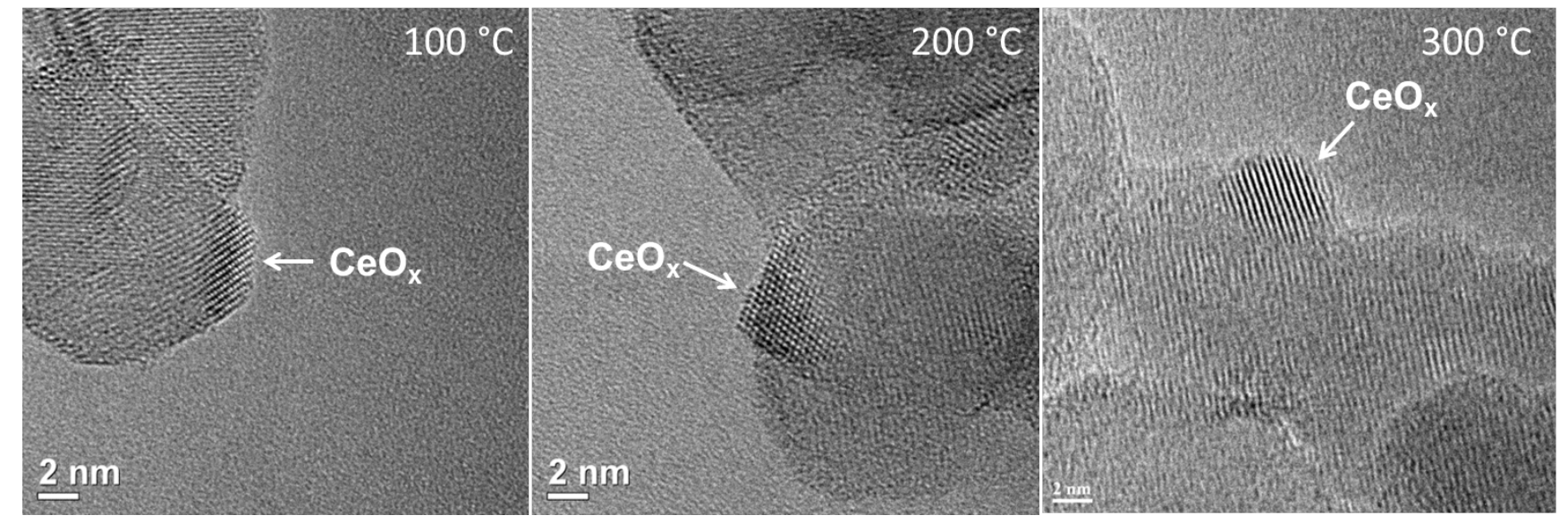

Figure 6. In situ environmental TEM images of $6 \mathrm{wt} \% \mathrm{CeO}_{\mathrm{x}}-\mathrm{TiO}_{2}$ sample at 100, 200 and $300{ }^{\circ} \mathrm{C}$ in $1.1 \times 10^{-1}$ torr $\mathrm{H}_{2}$.

WGS activity study and structure change under reaction condition: In situ XRD and in situ DRIFTS

The catalytic WGS reaction on PtxCeTi catalysts was monitored by in situ XRD and DRIFTS at different temperatures. As shown in Fig. 7, $\mathrm{CO}_{2}$ product gas outflow analysis by RGA over 0.5\% Pt loaded $\mathrm{CeO}_{x}-\mathrm{TiO}_{2}$ catalysts yields a clear trend in water-gas shift activity at different heating ramp temperatures as follows: $1 \% \mathrm{CeO}_{\mathrm{x}}>3 \% \mathrm{CeO}_{\mathrm{x}}>6 \% \mathrm{CeO}_{\mathrm{x}}$. In contrast, plain $\mathrm{TiO}_{2}$ and $\mathrm{CeO}_{\mathrm{x}}-\mathrm{TiO}_{2}$ show no water-gas shift activity (not shown here). It may therefore be inferred from the crucial role of Pt on the $\mathrm{CeO}_{\mathrm{x}}-\mathrm{TiO}_{2}$ support in activating these materials as water gas shift catalysts. As showed by STEM (Figure S2) Pt is dispersed on the surface of the material as nanoparticles with the size of 1 2 nm. The addition of Pt does not change the surface area of each catalyst as shown in supporting information (Figure S3). The Pt1CeTi system is the most active catalyst for WGS reaction regardless of the reaction temperature compared to others containing higher loading contents of $\mathrm{CeO}_{\mathrm{x}}$. 


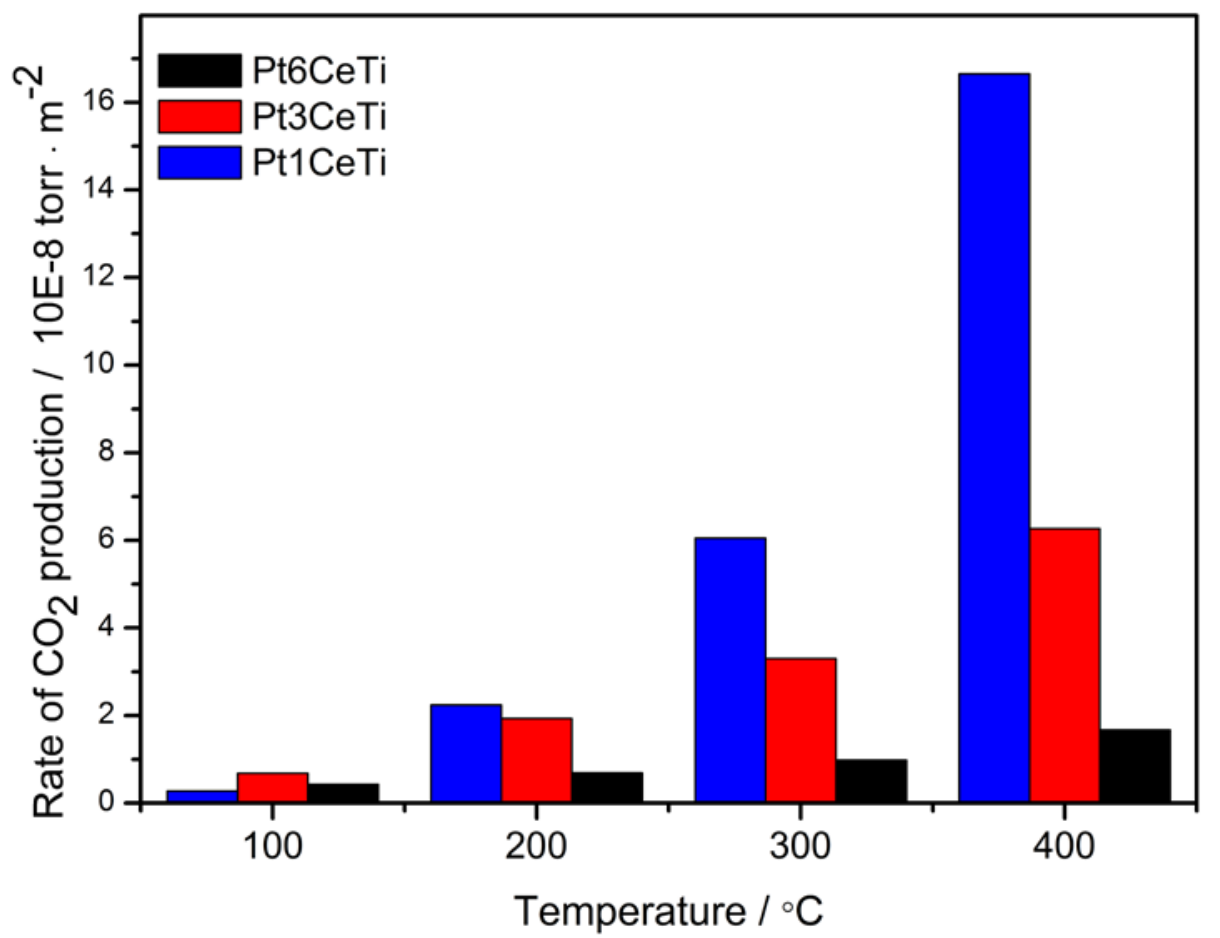

Figure 7. Water gas shift activity measured in a flow reactor by RGA during the water-gas shift reaction onto PtxCeTi series with different $\mathrm{CeO}_{\mathrm{x}}$ loading and normalized to the surface area of the catalysts. (Original mass spectra measuring the partial pressure of $\mathrm{CO}_{2}$ and $\mathrm{H}_{2}$ were shown in the supporting information Figure S4)

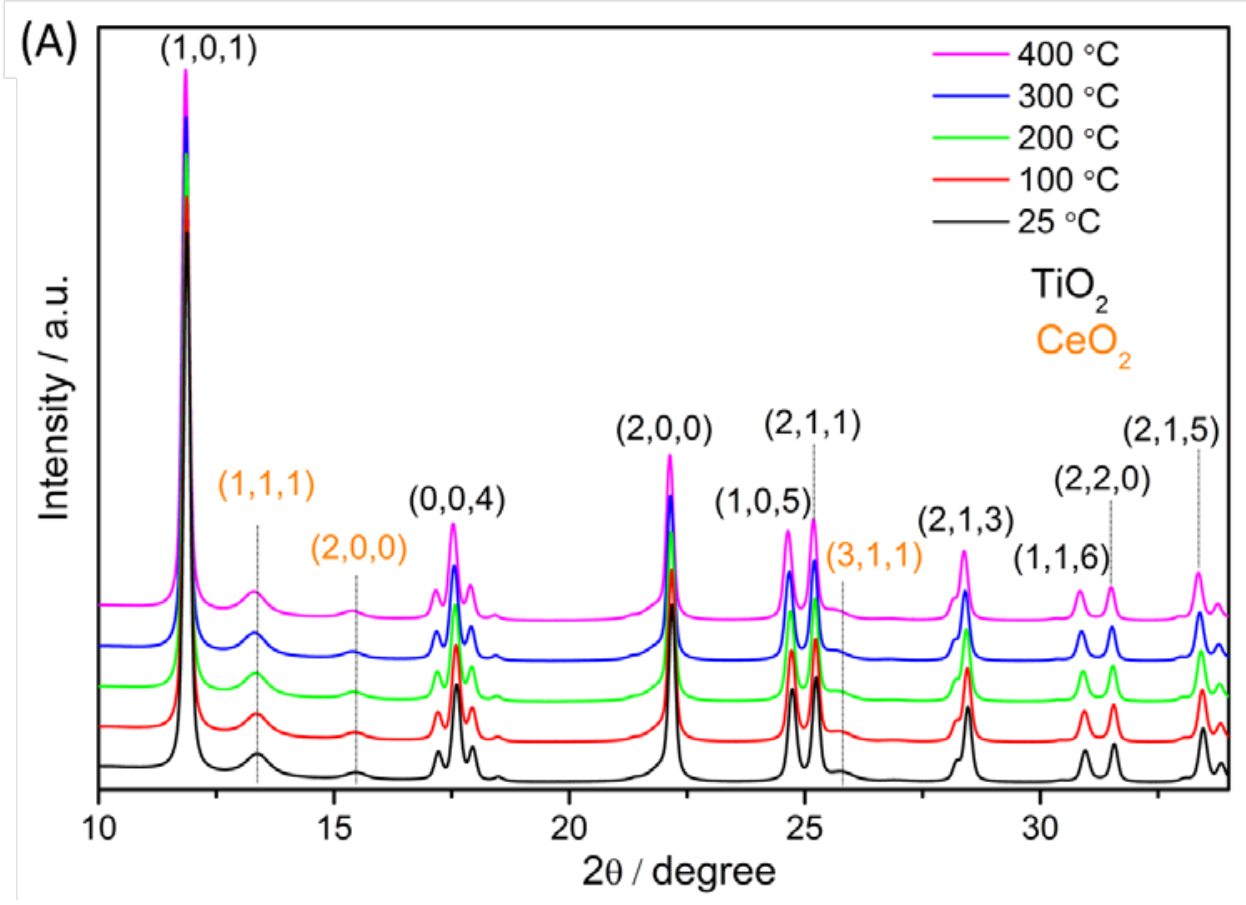




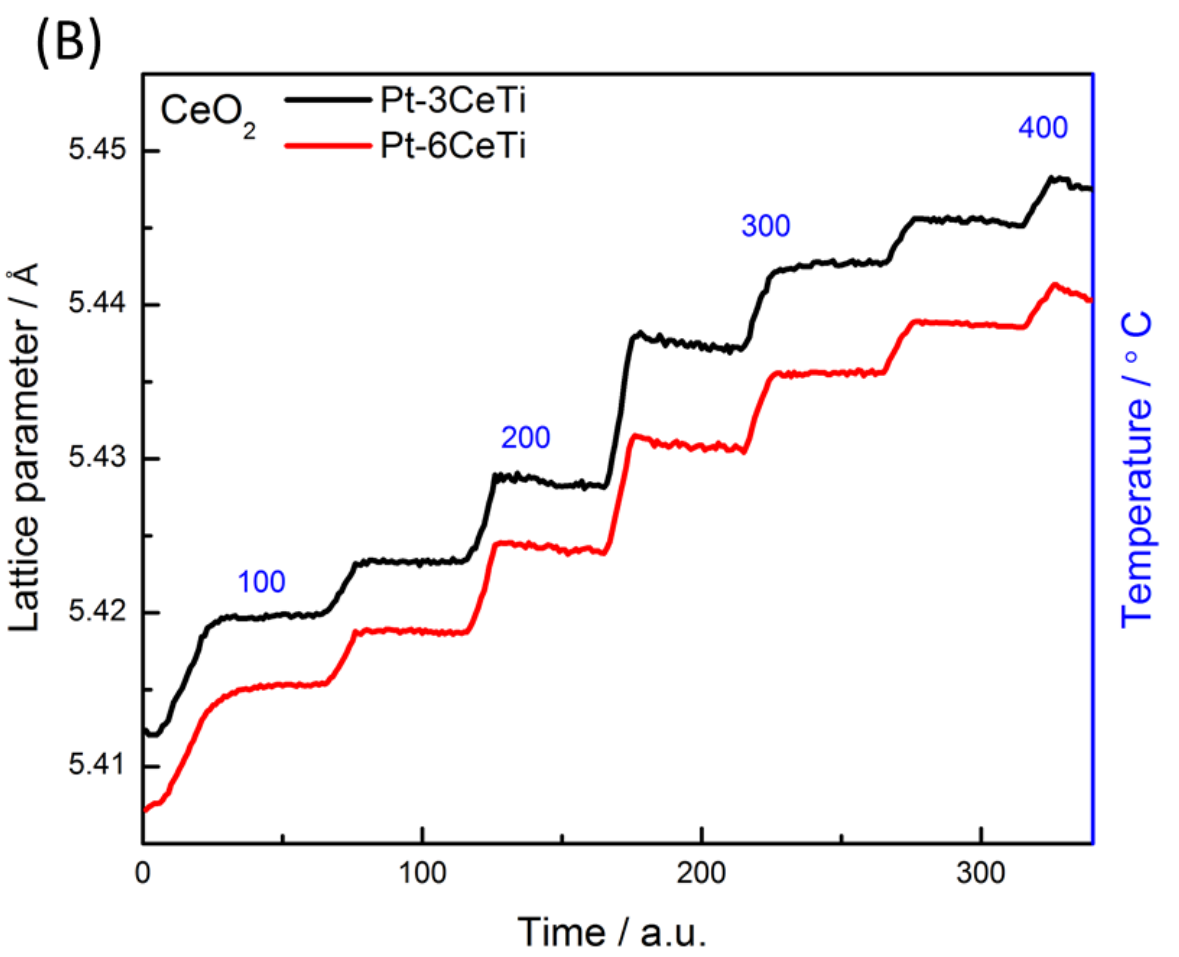

Figure 8 (A) In situ XRD patterns of Pt3CeTi and Pt6CeTi catalysts under WGS reaction conditions as a function of temperature; (B) lattice parameter of $\mathrm{CeO}_{2}$ sequentially refined from in situ XRD.

As reported previously, ${ }^{19}$ the anatase phase of the $\mathrm{TiO}_{2}$ support was identified by synchrotron X-ray diffraction and X-ray absorption techniques together with small signals of $\mathrm{CeO}_{2}$ fluorite-type structure at moderate to high loading content (3 and $6 \mathrm{wt} \%$ ). After loading the Pt nanoparticles, the crystallographic phase of $\mathrm{TiO}_{2}$ was unchanged. Fig. 8(A) shows in situ XRD pattern for the WGS reaction on the Pt6CeTi catalyst where numerous diffractions at $2 \theta=11.8,17.5,22.1$ and $24.6^{\circ}$ were assigned to (101), (004), (200) and (105) plane of anatase $\mathrm{TiO}_{2}$ (space group $\mathrm{I}_{1} / \mathrm{amd}$ ); some small diffraction peaks at $2 \theta=13.4,15.5$ and $25.8^{\circ}$ were assigned to (111), (200) and (311) plane of cubic fluorite $\mathrm{CeO}_{2}$ at room temperature. As the temperature increased under WGS reaction conditions, $\mathrm{TiO}_{2}$ remained in the anatase phase up to $400{ }^{\circ} \mathrm{C}$ with no obvious change in the diffraction patterns. $\mathrm{CeO}_{2}$ in its cubic fluorite phase was also observed during the process of the WGS reaction. The sequential Rietveld refinement analysis of fluorite-type $\mathrm{CeO}_{2}$ for Pt loaded $3 \%$ and $6 \% \mathrm{CeO}_{\mathrm{x}}-\mathrm{TiO}_{2}$ catalysts obtained from in situ XRD patterns that were carried out under WGS reaction condition are plotted in 
Fig. 8(B). Due to a very low loading, the refinement of the ceria lattice on the Pt1CeTi sample was impossible to conduct. The lattice parameters of $\mathrm{CeO}_{2}$ on Pt3CeTi and Pt6CeTi at room temperature are 5.412 and $5.407 \AA$, respectively, which is consistent with the literature. ${ }^{17,24}$ Under WGS reaction conditions, thermal expansion of the lattice occurred in both catalysts ${ }^{25}$ However, an abrupt expansion of the lattice was found at the temperature between $200^{\circ} \mathrm{C}$ and $250^{\circ} \mathrm{C}$, suggesting the partial reduction of $\mathrm{Ce}^{4+}$ to $\mathrm{Ce}^{3+}$ and the consequential formation of oxygen vacancies. ${ }^{11,26,27}$ Such an extent of ceria reduction is bigger for $\mathrm{Pt} 3 \mathrm{CeTi}$ possibly due to a lower particle size $\mathrm{e}^{19}$ since the reduction of ceria strongly depends on the ceria crystallite size. ${ }^{27}$ This expansion occurs concurrently with the initial observed water-gas shift activity. Similarly, a sharp contraction of the ceria lattice was observed as the temperature decreased from $200^{\circ} \mathrm{C}$ to $150^{\circ} \mathrm{C}$ upon cooling of the catalysts, indicating the oxidation of the ceria lattice. Thermal expansion of the $\mathrm{TiO}_{2}$ cell (both a and c parameters) follow the normal evolution with temperature without the abrupt changes observed in the $\mathrm{CeO}_{2}$, suggesting that no changes in the titania oxidation state occur during WGS reaction conditions.

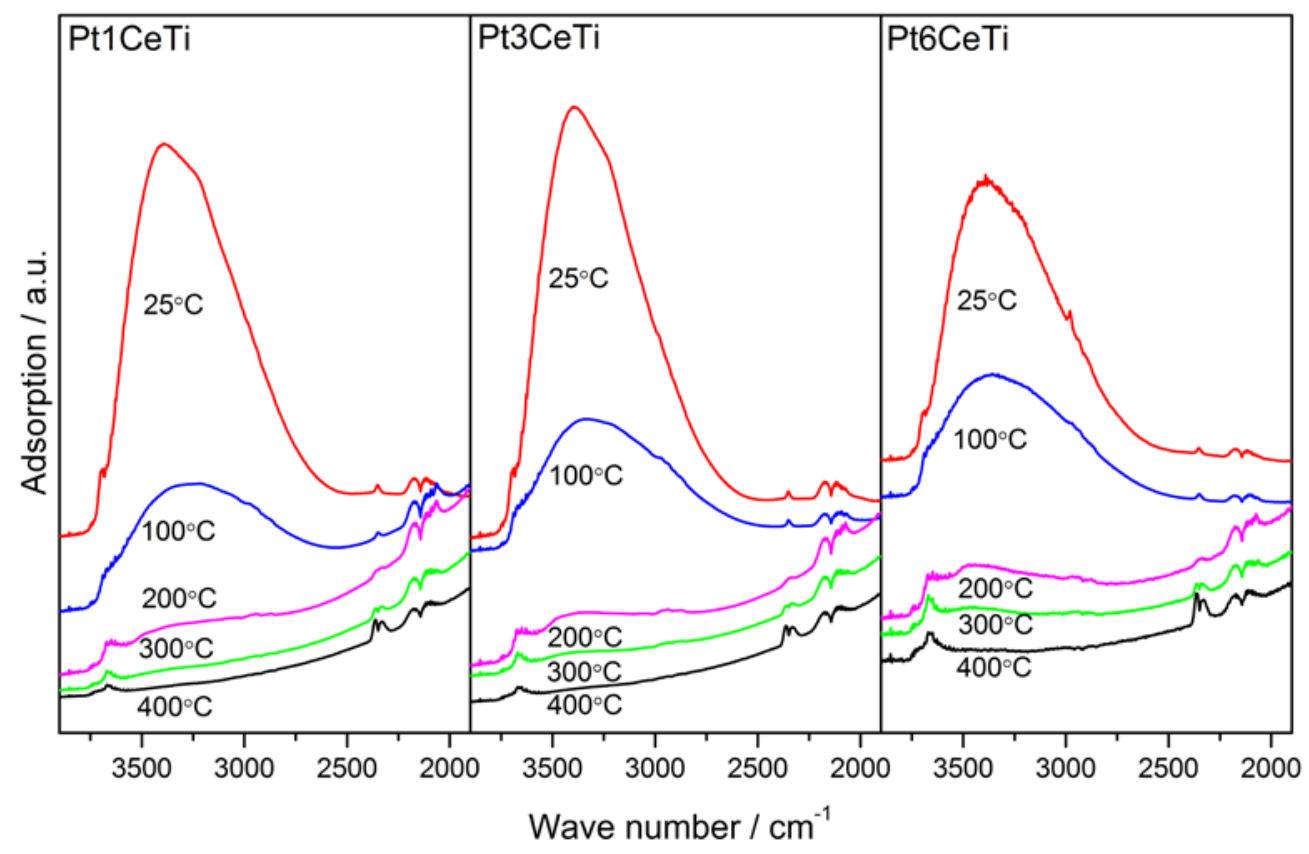

Figure 9. In situ DRIFTS under WGS reaction conditions at different temperatures over Pt1CeTi, Pt3CeTi and Pt6CeTi catalysts 
Fig. 9 shows in situ DRIFTS data for the WGS on $\mathrm{Pt} / \mathrm{CeO}_{\mathrm{x}}-\mathrm{TiO}_{2}$ samples with different $\mathrm{CeO}_{\mathrm{x}}$ loadings. The similar surface species were observed for the three catalysts (shown in different panels from left to right) at each temperature step. At room temperature, a large broad band in the region of $3200-3700$ $\mathrm{cm}^{-1}$ accompanied with smaller band at $3660 \mathrm{~cm}^{-1}$ are ascribed to the molecular adsorbed water and stretching vibration of surface doubly bridging hydroxyl groups, respectively. ${ }^{14,29-31}$ This band sharply decreases with increasing the temperature to $200{ }^{\circ} \mathrm{C}$ and completely disappears at higher temperature. Another small band at $c a$. $2345 \mathrm{~cm}^{-1}$ corresponds to adsorbed $\mathrm{CO}_{2}$. In the $2000-2300 \mathrm{~cm}^{-1}$ region, a broad doublet centered at $2143 \mathrm{~cm}^{-1}$ is present due to CO in the gas phase. As temperature increases to $200{ }^{\circ} \mathrm{C}$, two peaks arise at $2060 \mathrm{~cm}^{-1}$ and $2085 \mathrm{~cm}^{-1}$, which are assigned to the strongly bound carbonyl species (i.e. bridging carbonyls) linearly adsorbed on metallic $\mathrm{Pt}$ and also to $\mathrm{Pt}-\mathrm{H}$ stretching vibrations $s^{30,32}$ and these bands gradually diminish due to desorption at higher temperature. The doublet band at $2330 \mathrm{~cm}^{-1}$ and $2360 \mathrm{~cm}^{-1}$ grows up due to the production of gas phase $\mathrm{CO}_{2}$ after a further increase of the temperature to 300 and $400{ }^{\circ} \mathrm{C}$, indicating the facilitation of the WGS reaction. ${ }^{33}$ Besides, a Fermi resonance doublet in the 2700-3000 $\mathrm{cm}^{-1}$ region immersed in the water/OH bands shows up, indicating the presence of formate $\left(\mathrm{HCOO}^{-}\right)$species, in particular, $v(\mathrm{C}-\mathrm{H})$ stretching band at $\sim 2940 \mathrm{~cm}^{-1}$ and a combination $\delta(\mathrm{C}-\mathrm{H})$ bending mode and symmetric OCO stretches, $v_{\mathrm{s}}(\mathrm{OCO}), \sim 2840$ $\mathrm{cm}^{-1} \cdot{ }^{10,32}$ It has been reported that along with carbonate species, formate species are key intermediates in the WGS on ceria-based systems and formed by water dissociation with subsequent reaction of hydroxyl groups and CO.,11,34,35 The formate bands vanish at $400{ }^{\circ} \mathrm{C}$ when the $\mathrm{CO}_{2}$ production reaches the maximum. It is clear that much higher WGS activity was obtained at this temperature for all three catalysts; and both experimental and theoretical studies have recently demonstrated that the formate species are typically spectators and not truly intermediate species of the WGS mechanism. ${ }^{5,14,36,37}$ It can be concluded that the catalysts with different $\mathrm{CeO}_{\mathrm{x}}$ concentration undergo the similar reaction pathway involving the formation of identical intermediate species adsorbed on the surface during the WGS reaction. Specifically, the formate bands appears at room temperature in Pt3CeTi and Pt6CeTi 
catalysts and its intensity is proportional to the $\mathrm{CeO}_{\mathrm{x}}$ loading content, suggesting the accumulation of formate species that is mostly accomplished by ceria on the surface. Otherwise, the doubly bridging hydroxyl groups at $3660 \mathrm{~cm}^{-1}$ in Pt6CeTi is more intense than in the others as the reaction temperature is increased to $400{ }^{\circ} \mathrm{C}$, together with an emerging shoulder at $\sim 3730 \mathrm{~cm}^{-1}$, which is attributed to the single coordinated hydroxyl groups (type I, also $\mathrm{OH}$ unidentate) and bridging $\mathrm{OH}$ groups at oxygen vacancies. $^{2,29,30,32}$ It is frequent that the bridging $\mathrm{OH}$ group associated with oxygen vacancies is dominant on reduced ceria surfaces while vertical $\mathrm{OH}$ on ceria is more intense on oxidized ceria. We have reported in a previous study that Pt6CeTi contains more oxidized ceria $\left(\mathrm{Ce}^{4+}\right.$ states) whereas Pt1CeTi catalysts is highly dominated by $\mathrm{Ce}^{3+} \cdot{ }^{19}$ Ultrafine $\mathrm{CeO}_{\mathrm{x}}$ clusters supported on $\mathrm{TiO}_{2}$ could be easily reduced under WGS reaction condition, leading to the domination of reduced species and the highest WGS activity up to $400{ }^{\circ} \mathrm{C}$; meanwhile, larger $3 \mathrm{D} \mathrm{CeO}_{2}$ particles on $\mathrm{TiO}_{2}$ in $\mathrm{Pt} 6 \mathrm{CeTi}$ could be partially reduced due to significant amount of bulk $\mathrm{CeO}_{2}$, resulting in lower activity.

\section{CONCLUSIONS}

We interrogated the importance of low dimensional $\mathrm{CeO}_{\mathrm{x}}$ on the $\mathrm{TiO}_{2}$ support in $\mathrm{Pt} / \mathrm{CeO}{ }_{\mathrm{x}}-\mathrm{TiO}_{2}$ catalysts for the WGS reaction using in situ operando XRD and DRIFTS studies. The two-stage crystal growth of ceria crystallite on $\mathrm{TiO}_{2}$ nanoparticle: fine crystallite formed at $\sim 250{ }^{\circ} \mathrm{C}$, followed by crystal growth into $2 \mathrm{D}$ chain and $3 \mathrm{D}$ particle from $250 \sim 400{ }^{\circ} \mathrm{C}$ growth process of ceria crystallite on $\mathrm{TiO}_{2}$ nanoparticle was observed by means of TGA/DTA, time-resolved in situ XRD, PDF and STEM. As promising catalysts for WGS reaction, we also endeavored to prove the enhanced reducibility through $\mathrm{H}_{2}$-TPR and robust thermal stability by in situ environmental TEM. The catalyst involving ultrafine dispersed one-dimensional (1D) $\mathrm{CeO}_{\mathrm{x}}$ clusters smaller than $1 \mathrm{~nm}$ exhibited the highest WGS activity and much enhanced reducibility, compared to the catalysts containing higher $\mathrm{CeO}_{\mathrm{x}}$ loadings in higher dimensional geometries. 


\section{Supporting Information}

The supporting information is available free of charge on the ACS Publications website at http://pubs.acs.org. This content includes several data sets including X-ray diffraction fitting of $\mathrm{CeO}_{\mathrm{x}^{-}}$ $\mathrm{TiO}_{2}$ catalysts, STEM images of Pt particles in the $\mathrm{Pt} / \mathrm{CeO}_{\mathrm{x}}-\mathrm{TiO}_{2}$ catalysts, surface area comparisons between catalysts, and reactivity data of catalysts under reaction conditions.

\section{Acknowledgements}

This work was supported by the U.S. Department of Energy, Office of Science, Office of Basic Energy Sciences, and Catalysis Science Program under contract No. DE-SC0012704. This work used resources of the Center for Functional Nanomaterials (CFN), the National Synchrotron Light Source (NSLS) at BNL, and the Advanced Photon Source (17BM) of Argonne National Laboratory (No. DEAC02-06CH11357) which are all DOE Office of Science User Facilities. 


\section{REFERENCES}

1. Rodriguez, J. A.; Ma, S.; Liu, P.; Hrbek, J.; Evans, J.; Pérez, M. Activity of $\mathrm{CeO}_{\mathrm{x}}$ and $\mathrm{TiO}_{\mathrm{x}}$ Nanoparticles Grown on Au(111) in the Water-Gas Shift Reaction. Science 2007, 318, 1757-1760.

2. Meunier, F. C.; Goguet, A.; Hardacre, C.; Burch, R.; Thompsett, D. Quantitative Drifts Investigation of Possible Reaction Mechanisms for the Water-Gas Shift Reaction on HighActivity Pt- and Au-Based Catalysts. J. Catal. 2007, 252, 18-22.

3. Graf, P. O.; de Vlieger, D. J. M.; Mojet, B. L.; Lefferts, L. New Insights in Reactivity of Hydroxyl Groups in Water Gas Shift Reaction on Pt/ZrO 2. J. Catal. 2009, 262, 181-187.

4. Rodriguez, J. A. Gold-based Catalysts for The Water-Gas Shift Reaction: Active Sites and Reaction Mechanism. Catal. Today 2011, 160, 3-10.

5. Kalamaras, C. M.; Dionysiou, D. D.; Efstathiou, A. M. Mechanistic Studies of the Water-Gas Shift Reaction over Pt/Ce $\mathrm{Zr}_{1-\mathrm{x}} \mathrm{O}_{2}$ Catalysts: The Effect of Pt Particle Size and Zr Dopant. ACS Catal. 2012, 2, 2729-2742.

6. Yao, S. Y.; Xu, W. Q.; Johnston-Peck, A. C.; Zhao, F. Z.; Liu, Z. Y.; Luo, S.; Senanayake, S. D.; Martínez-Arias, A.; Liu, W. J.; Rodriguez, J. A. Morphological Effects of the Nanostructured Ceria Support on the Activity and Stability of $\mathrm{CuO} / \mathrm{CeO}_{2}$ Catalysts for the Water-Gas Shift Reaction. Phys. Chem. Chem. Phys. 2014, 16, 17183-17195.

7. Zhu, M.; Wachs, I. E. Iron-Based Catalysts for the High-Temperature Water-Gas Shift (HT-WGS) Reaction: A Review. ACS Catal. 2016, 6, 722-732.

8. Burch, R. Gold Catalysts for Pure Hydrogen Production in the Water-Gas Shift. Phys. Chem. Chem. Phys. 2006, 47, 5483-5500.

9. Rodriguez, J.A.; Liu, P.; Hrbek, J.; Evans, J.; Pérez, M. Water Gas Shift Reaction on Cu and Au Nanoparticles Supported on $\mathrm{CeO}_{2}(111)$ and $\mathrm{ZnO}(0001)$ : Intrinsic Activity and Importance of Support Interactions. Angew. Chem. Int. Ed. 2007, 46, 1329-1332. 
10. Vignatti, C.; Avila, M. S.; Apesteguía, C. R.; Garetto, T. F. Catalytic and Drifts Study of the WGS Reaction on Pt-Based Catalysts. Int. J. Hydrogen Energy 2010, 35, 7302-7312.

11. Barrio, L.; Kubacka, A.; Zhou, G.; E., Michael; Martínez-Arias, A.; Hanson, J. C.; FernándezGarcía, M.; Rodriguez, J. A., Unusual Physical and Chemical Properties of Ni in $\mathrm{Ce}_{1-\mathrm{x}} \mathrm{Ni}_{\mathrm{x}} \mathrm{O}_{2-\mathrm{y}}$ Oxides: Structural Characterization and Catalytic Activity for the Water Gas Shift Reaction. J. Phys. Chem. C 2010, 114, 12689-12697.

12. Xu, W. Q.; Si, R.; Senanayake, S. D.; Llorca, J.; Idriss, H.; Stacchiola, D.; Hanson, J. C.; Rodriguez, J. A. In Situ Studies of $\mathrm{CeO}_{2}$-Supported Pt, $\mathrm{Ru}$, and Pt-Ru Alloy Catalysts for the Water-Gas Shift Reaction: Active Phases and Reaction. J. Catal. 2012, 291, 117-126.

13. Barrio, L.; Zhou, G.; González, I. D.; Estrella, M.; Hanson, J.; Rodriguez, J. A.; Navarro, R. M.; Fierro, J. L. G. In Situ Characterization of Pt Catalysts Supported on Ceria Modified $\mathrm{TiO}_{2}$ for the WGS Reaction: Influence of Ceria Loading. Phys. Chem. Chem. Phys. 2012, 14, 2192-2202.

14. Zhao, F.; Liu, Z.; Xu, W.; Yao, S.; Kubacka, A.; Johnston-Peck, A. C.; Senanayake, S. D.; Zhang, A.-Q.; Stach, E. A.; Fernández-García, M. et al. A. Water-Gas Shift Reaction on Ni-W-Ce Catalysts: Catalytic Activity and Structural Characterization. J. Phys. Chem. C 2014, 118, 25282538.

15. Ashok, J.; Ang, M. L.; Terence, P. Z. L.; Kawi, S. Promotion of the Water-Gas-Shift Reaction by Nickel Hydroxyl Species in Partially Reduced Nickel-Containing Phyllosilicate Catalysts. Chem. Cat. Chem. 2016, 8, 1308-1318.

16. Sener, C.; Wesley, T. S.; Alba-Rubio, A. C.; Kumbhalkar, M. D.; Hakim, S. H.; Ribeiro, F. H.; Miller, J. T.; Dumesic, J. A. PtMo Bimetallic Catalysts Synthesized by Controlled Surface Reactions for Water Gas Shift. ACS Catal. 2016, 6, 1334-1344.

17. S. Tsunekawa; K. Ishikawa; Z. Q. Li; Y. Kawazoe and A. Kasuya. Origin of Anomalous Lattice Expansion in Oxide Nanoparticles. Phys. Rev. Lett., 2000, 85, 3440. 
18. M. D. Hernandez-Alonso; A. B. Hungria; A. Martinez-Arias; J. M. Coronado; J. C. Conesa; J. Soria and M. Fernandez-Garcia. Confinement effects in quasi-stoichiometric CeO2 nanoparticles. Phys. Chem. Chem. Phys., 2004, 6, 3524.

19. Luo, S.; Nguyen-Phan, T. D.; Johnston-Peck, A. C.; Barrio, L.; Sallis, S.; Arena, D. A.; Kundu, S.; Xu, W. Q.; Piper, L. F. J.; Stach, E. A., et al. Hierarchical Heterogeneity at the $\mathrm{CeO}_{\mathrm{x}}-\mathrm{TiO}_{2}$ Interface: Electronic and Geometric Structural Influence on the Photocatalytic Activity of Oxide on Oxide Nanostructures. J. Phys. Chem. C 2015, 119, 2669-2679.

20. Toby, B. H., Von Dreele, R. B. GSAS-II: The Genesis of a Modern Open-Source All Purpose Crystallography Software Package. J. Appl. Crystallogr. 2013, 46, 544-549.

21. Marinkovic, N. S.; Wang, Q.; Frenkel, A. I. In Situ Diffuse Reflectance IR Spectroscopy and Xray Absorption Spectroscopy for Fast Catalytic Processes. J. Synchrotron Rad. 2011, 18, 447-455.

22. Watanabe, S.; Ma, X.; Song, C. Characterization of Structural and Surface Properties of Nanocrystalline $\mathrm{TiO}_{2}-\mathrm{CeO}_{2}$ Mixed Oxides by XRD, XPS, TPR, and TPD. J. Phys. Chem. C 2009, 113, 14249-14257.

23. Larsson, P. O.; Andersson, A. Complete Oxidation of CO, Ethanol, and Ethyl Acetate over Copper Oxide Supported on Titania and Ceria Modified Titania. J. Catal. 1998, 179, 72-81.

24. Pojanavaraphan, C.; Luengnaruemitchai, A.; Gulari, E. Effect of Catalyst Preparation on $\mathrm{Au} / \mathrm{Ce}_{1-\mathrm{x}} \mathrm{Zr}_{\mathrm{x}} \mathrm{O}_{2}$ and $\mathrm{Au}-\mathrm{Cu} / \mathrm{Ce}_{1-\mathrm{x}} \mathrm{Zr}_{\mathrm{x}} \mathrm{O}_{2}$ for Steam Reforming of Methanol. Int. J. Hydrogen Energy 2013, 38, 1348-1362.

25. Fernández-Garcia, M.; Wang, X. Q.; Belver, C.; Iglesias-Juez, A.; Hanson, J. C.; Rodriguez, J. A. Ca Doping of Nanosize Ce-Zr and Ce-Tb Solid Solutions: Structural and Electronic Effects. Chem. Mater. 2005, 17, 4181-4193.

26. Rodriguez, J. A.; Hanson, J. C.; Kim, J.-Y.; Liu, G.; Iglesias-Juez, A.; Fernández-García, M. Properties of $\mathrm{CeO}_{2}$ and $\mathrm{Ce}_{1-\mathrm{x}} \mathrm{Zr}_{\mathrm{x}} \mathrm{O}_{2}$ Nanoparticles: X-ray Absorption Near-Edge Spectroscopy, 
Density Functional, and Time-Resolved X-ray Diffraction Studies. J. Phys. Chem. B. 2003, 107, 3535-3543.

27. Wang, X.; Hanson, J. C.; Rodriguez, J. A.; Belver, C.; Fernández-García, M. The Structural and Electronic Properties of Nanostructured $\mathrm{Ce}_{1-\mathrm{x}-\mathrm{y}} \mathrm{Zr}_{\mathrm{x}} \mathrm{Tb}_{\mathrm{y}} \mathrm{O}_{2}$ Ternary Oxides: Unusual Concentration of $\mathrm{Tb}^{3+}$ and Metal $\leftrightarrow$ Oxygen $\leftrightarrow$ Metal Interactions. J. Chem. Phys. 2005, 122, 154711.

28. Giordano, F.; Trovarelli, A.; de Leitenburg, C.; Giona, M. A Model for the TemperatureProgrammed Reduction of Low and High Surface Area Ceria. J. Catal. 2000, 193, 273-282.

29. Badri, A.; Binet, C.; Lavalley, J. C. An FTIR Study of Surface Ceria Hydroxyl Groups during a Redox Process with $\mathrm{H}_{2}$. J. Chem. Soc., Faraday Trans. 1996, 92, 4669-4673.

30. Meunier, F. C.; Tibiletti, D.; Goguet, A.; Reid, D.; Burch, R. On the Reactivity of Carbonate Species on a Pt/CeO 2 Catalyst under Various Reaction Atmospheres: Application of the Isotopic Exchange Technique. Appl. Catal. A Gen. 2005, 289, 104-112.

31. Soykal, I. I.; Sohn, H.; Ozkan, U. S. Effect of Support Particle Size in Steam Reforming of Ethanol over Co/CeO 2 Catalysts. ACS Catal. 2012, 2, 2335-2348.

32. Holmgren, A.; Andersson, B.; Duprez, D. Interactions of CO with Pt/Ceria Catalysts. Appl. Catal. B: Environ. 1999, 22, 215-230.

33. Wu, Z.; Li, M.; Overbury, S. H. On the Structure Dependence of CO Oxidation over $\mathrm{CeO}_{2}$ Nanocrystals with Well-Defined Surface Planes. J. Catal. 2012, 285, 61-73.

34. Hočevar, S.; Krašovec, U. O.; Orel, B.; Aricó, A. S.; Kim, H. CWO of Phenol on Two Differently Prepared CuO-CeO ${ }_{2}$ Catalysts. Appl. Catal., B 2000, 28, 113-125.

35. Liu, Y.; Hayakama, T.; Suzuki, K.; Hamakawa, S., Production of Hydrogen by Steam Reforming of Methanol over $\mathrm{Cu} / \mathrm{CeO}_{2}$ Catalysts Derived from $\mathrm{Ce}_{1-\mathrm{x}} \mathrm{Cu}_{\mathrm{x}} \mathrm{O}_{2-\mathrm{x}}$ Precursors. Catal. Commun. 2001, 2, 195-200. 
36. Burch, R.; Goguet, A.; Meunier, F. C. A Critical Analysis of the Experimental Evidence for and against a Formate Mechanism for High Activity Water-Gas Shift Catalysts. Appl. Catal., A 2011, 409-410, 3-12.

37. Shinde, V. M.; Madras, G. Low Temperature CO Oxidation and Water Gas Shift Reaction over $\mathrm{Pt} / \mathrm{Pd}$ Substituted in $\mathrm{Fe} / \mathrm{TiO}_{2}$ Catalysts. Int. J. Hydrogen Energy 2012, 37, 18798-18814. 
TOC Graphic

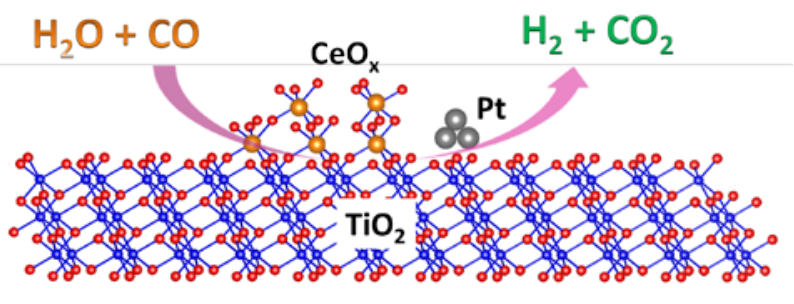

